\title{
Temporal stability of soil moisture in banana cropping area in the Brazilian semiarid region
}

\author{
Diego C. dos S. Araújo ${ }^{1}$, Suzana M. G. L. Montenegro ${ }^{2}$, Abelardo A. de A. Montenegro', \\ Daniella P. dos Santos ${ }^{1} \&$ Renato A. S. Rodrigues ${ }^{1}$
}

${ }^{1}$ Universidade Federal Rural de Pernambuco/Departamento de Engenharia Agrícola. Recife, PE, Brasil. E-mail: diego@agro.eng.br (Corresponding author) - ORCID: 0000-0002-8969-260X; abelardomontenegro666@gmail.com - ORCID: 0000-0002-5746-8574; daniellapsantos@hotmail.com - ORCID: 0000-0002-4450-0141; renato.augustor@hotmail.com - ORCID: 0000-0002-9329-9368

${ }^{2}$ Universidade Federal de Pernambuco/Departamento de Engenharia Civil. Recife, PE, Brasil. E-mail: suzanam.ufpe@gmail.com - ORCID: 0000-00022520-5761

\begin{abstract}
Soil moisture is essential for agricultural production. Knowledge on its spatial-temporal variability is indispensable to support agriculture, and it is strongly influenced by cultural practices, soil cover conditions and irrigation methods. Thus, this study aimed to evaluate the temporal stability and spatial distribution of soil moisture as a function of the use of banana leaves as soil cover in a plot under conventional sprinkler irrigation and cultivated with banana in the Brazilian semiarid region. The study area was divided in two sectors, with and without covering using banana leaves. Soil moisture was monitored before and after irrigation, at 16 times, using FALKER HidroFarm sensors installed on a transect with 11 units spaced by $8 \mathrm{~m}$, in each sector. The data were analyzed using descriptive statistics, temporal stability and Spearman correlation test. The morphology of the banana leaves and the irrigation system used contributed to lower soil moisture in the covered sector at all monitoring times. Variations in the physical-hydraulic properties of the soil promoted variations in soil moisture with the position of the sensors in the ground. The temporal stability technique allowed the identification of points that represent the mean behavior of soil moisture throughout the area. The use of banana leaf residues caused less soil wetting using sprinkler irrigation, indicating the need to pregrind the material or use localized irrigation systems, practices that are not very accessible to small farmers.
\end{abstract}

Key words: Musa spp., sprinkling, relative difference technique, soil mulching

\section{Estabilidade temporal da umidade do solo em cultivo de banana no semiárido brasileiro}

RESUMO: A umidade do solo é essencial para a produção agrícola. O conhecimento de sua variabilidade espaço-temporal é indispensável para suporte à agricultura, sendo fortemente influenciada pelas práticas culturais, condições de cobertura do solo e métodos de irrigação. Assim, este estudo teve como objetivo avaliar a estabilidade temporal e a distribuição espacial da umidade do solo em função do uso de folhas de bananeira como cobertura do solo em uma parcela sob irrigação por aspersão convencional e cultivada com banana na região semiárida brasileira. A área foi dividida em dois setores, sem e com cobertura do solo com folhas de bananeira. A umidade do solo foi monitorada, antes e após a irrigação, em 16 momentos, com o uso de sensores FALKER HidroFarm, instalados em um transecto com 11 unidades espaçadas em 8 m, em cada setor. Os dados foram analisados utilizando estatística descritiva, estabilidade temporal e teste de correlação de Spearman. A morfologia das folhas de bananeira e o sistema de irrigação utilizado contribuíram para diminuir a umidade do solo no setor coberto, em todos os momentos de monitoramento. Variações nas propriedades físico-hidráulicas do solo promoveram variações na umidade do solo com a posição dos sensores no solo. A técnica de estabilidade temporal permitiu identificar pontos que representam o comportamento médio da umidade do solo em toda a área. $\mathrm{O}$ uso de resíduos de folhas de bananeira causou menor umidade do solo com irrigação por aspersão, indicando a necessidade de pré-moer o material ou usar sistemas de irrigação localizados, práticas pouco acessíveis aos pequenos agricultores.

Palavras-chave: Musa spp., aspersão, técnica de diferença relativa, cobertura do solo

Ref. 209085 - Received 23 Jul, 2018 • Accepted 12 Sept, 2019 • Published 30 Sept, 2019 


\section{INTRODUCTION}

Banana (Musa spp.) is widely produced in all regions of Brazil. Due to the irregular distribution of rainfall in the semiarid region, its cultivation is only possible through irrigation (Rodrigues et al., 2017).

In Northeast region of Brazil, small farmers constitute more than $88 \%$ of the producers (Freire, 1999) and can generate about $50.2 \%$ of total agricultural production. Due to the lack of financial resources, the scarcity of technologies exposes these farmers to limitations that reduce yield, such as soils with low infiltration and low fertility and recurrent drought events that affect the semiarid region (Guanziroli et al., 2014).

One of the ways to minimize the impacts of water and nutrient scarcity is to use natural cover (Lopes et al., 2019), a conservation practice that may have a significant effect on the reduction of evapotranspiration, control of surface runoff and erosion, being of great accessibility and relevance for small farmers (Montenegro et al., 2013).

In banana cultivation, this management can be carried out with residues of the crop itself; however, it should be considered that banana leaves have structures that can act as a barrier to the passage of water and favor its accumulation, restricting soil wetting, depending on the irrigation system adopted, especially when water is distributed above the cover surface (Skutch, 1930).

Cintra et al. (2017) report that water may not adequately penetrate the material, causing water deficit, even with sufficient irrigation depths. More sophisticated irrigation techniques, such as drip and micro-sprinkler, have better efficiency, but are still a distant reality to small farmers.

Additionally, it is difficult to monitor soil moisture in the field (Brocca et al., 2017). One of the ways to overcome this problem is to adopt the temporal stability methodology, proposed by Vachaud et al. (1985), which assists in the more efficient monitoring of moisture content with reduced sampling effort and financial investment (Souza et al., 2011; Silva Junior et al., 2016).

Thus, this study aimed to evaluate the temporal stability and spatial distribution of soil moisture as a function of the use of banana leaves as soil cover in a plot under conventional sprinkler irrigation and cultivated with banana in the Brazilian semiarid region.

\section{Material ANd Methods}

The study was carried out in the period from November 26 to 28,2014 , in the municipality of Pesqueira, PE, Brazil, located in the Agreste Pernambucano mesoregion, with the following geographic coordinates: $-36^{\circ} 87^{\prime} \mathrm{W},-8^{\circ} 39^{\prime} \mathrm{S}$ and altitude of $645 \mathrm{~m}$. The region has a mean total annual rainfall of $730 \mathrm{~mm}$ and a mean annual potential evapotranspiration of $1683 \mathrm{~mm}$ (Montenegro \& Montenegro, 2006). According to Köppen's classification, the climate in the region is BSh (hot semiarid). The experimental area, granted to this study by the Fundação Terra, has $6,270 \mathrm{~m}^{2}$, cultivated with banana (Musa paradisiaca L.) at $4 \times 4 \mathrm{~m}$ spacing, in a total of 200 plants managed in a family farming system.
Irrigation was applied using a conventional sprinkler system, with below-crown sprinklers spaced by $6 \times 12 \mathrm{~m}$, with application intensity of $8.90 \mathrm{~mm} \mathrm{~h}^{-1}$ and mean water depth applied of $7.7 \mathrm{~mm}$. The operating pressure is $20 \mathrm{mwc}$, with throw diameter of $21.2 \mathrm{~m}$, uniformity coefficient (CUC) of $75.42 \%$ and interval of 3 days.

The soil of the study area is characterized as Entisol, with a sandy clay loam texture, according to a sampling performed at 104 points. Its mean density is $1.47 \mathrm{~kg} \mathrm{dm}^{-3}$, porosity is $0.52 \mathrm{~cm}^{3} \mathrm{~cm}^{-3}$, with moisture contents at field capacity and permanent wilting point of 0.181 and $0.09 \mathrm{~cm}^{3} \mathrm{~cm}^{-3}$, respectively. The measurements of position and dispersion for the variables hydraulic conductivity and sand, clay and silt contents, measured during the data collection period, can be observed in Table 1. The hydraulic conductivity was obtained by the Beerkan methodology (Santos et al., 2018).

During the studied period, maps of distribution of the particle-size fractions sand and silt (56 x $40 \mathrm{~m}$ grid), as well as of hydraulic conductivity ( $80 \times 30 \mathrm{~m}$ grid) were generated by geostatistical techniques, based on samplings made at 104 points (sand and silt) and 50 points (saturated hydraulic conductivity). In both cases, sampling was performed only in part of the plot, prioritizing the central portion and disregarding the marginal areas.

The maps of sand and silt fractions and hydraulic conductivity are represented in Figure 1, as well as the experimental area layout, with the location of plants and sensors' installation points. To evaluate the influence of the cover composed of banana leaves discarded after pruning, the plot was divided into two sectors, each containing 100 plants. Cover was applied in one of the sectors, while in the other the soil was kept in its original condition.

The dried banana leaves resulting from pruning were left directly on the soil, uniformly distributed, simulating conditions that could facilitate the reuse of this material by small farmers with no additional treatment and also aiming to verify whether the sprinkler irrigation system associated with this condition of high water interception could interfere in the distribution of water in the soil, since it is applied on leaf surface. Banana leaves have a large sheath with conical shape (used to fix the leaf to the stem) and two opposite blades with large surface (Skutch, 1930), forming structures that can act as a barrier to the passage of water and favor its accumulation, restricting soil wetting.

The cover was monitored by capturing digital images in a $0.50 \times 0.50 \mathrm{~m}$ grid in order to obtain an index of covered area along the surface. The processing was carried out using the SPRING-DPI/INPE geographic information system, according

Table 1. Values of soil physical-hydraulic attributes of the study area, based on sampling performed at 0-0.20 m layer

\begin{tabular}{|c|c|c|c|c|}
\hline \multirow{2}{*}{$\begin{array}{c}\text { Descriptive } \\
\text { statistics }\end{array}$} & \multirow{2}{*}{$\begin{array}{c}\mathrm{Ks}\left(\mathrm{mm} \mathrm{s}^{-1}\right) \\
(\mathrm{n}=50)\end{array}$} & Sand & Clay & Silt \\
\hline & & \multicolumn{3}{|c|}{$\left(\right.$ dag $\left.\mathrm{kg}^{-1}\right)(\mathrm{n}=104)$} \\
\hline $1^{\text {st }}$ Quartile & 0.069 & 63.44 & 25.76 & 21.70 \\
\hline Median & 0.142 & 59.38 & 23.76 & 16.20 \\
\hline Mean & 0.183 & 58.63 & 24.17 & 17.20 \\
\hline $3^{\text {rd }}$ Quartile & 0.222 & 53.43 & 21.76 & 14.30 \\
\hline Standard deviation & 0.163 & 5.89 & 3.49 & 5.36 \\
\hline
\end{tabular}

Ks - saturated hydraulic conductivity; $\mathrm{n}$ - number of points in which sampling was performed 

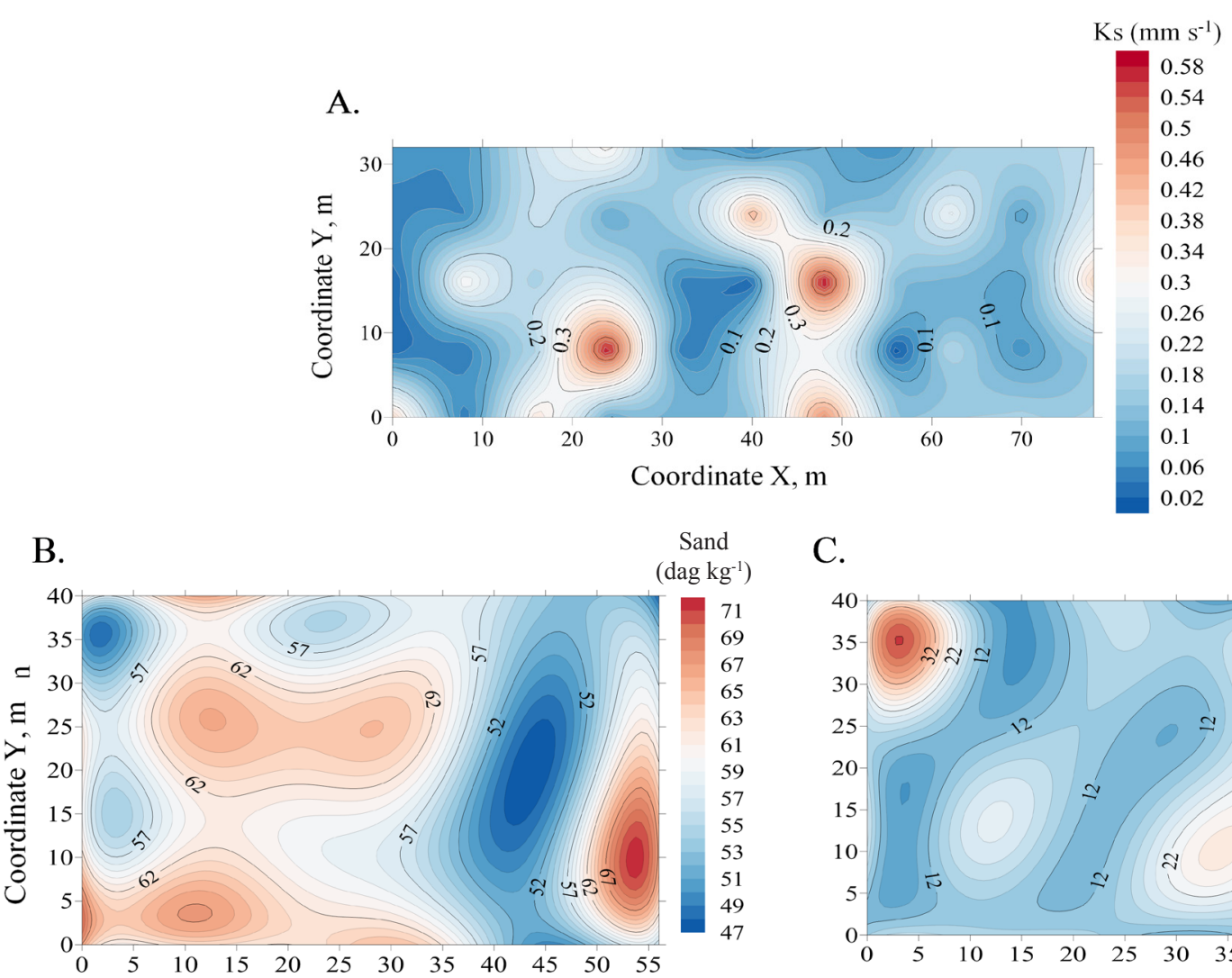

C.

Coordinate X, m

D.

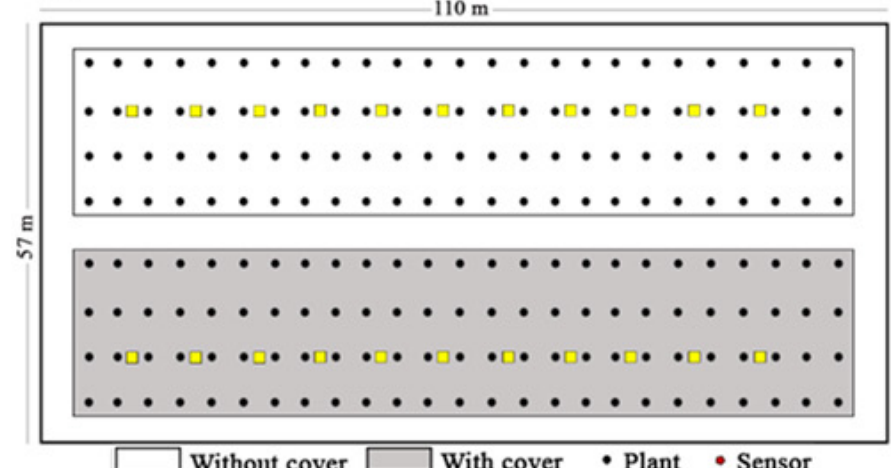

E.

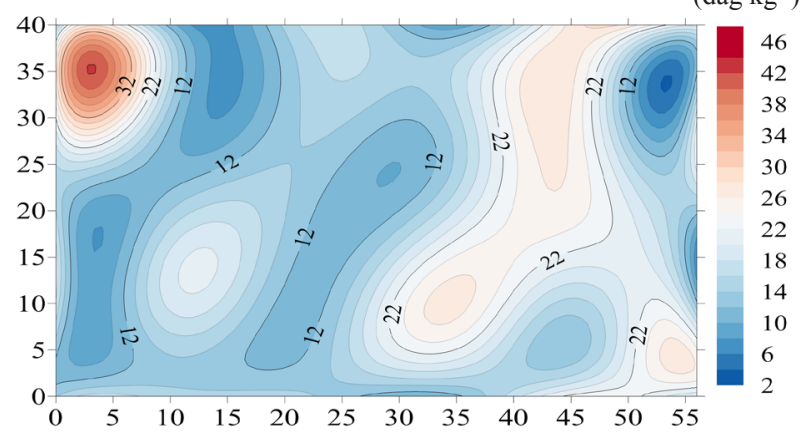

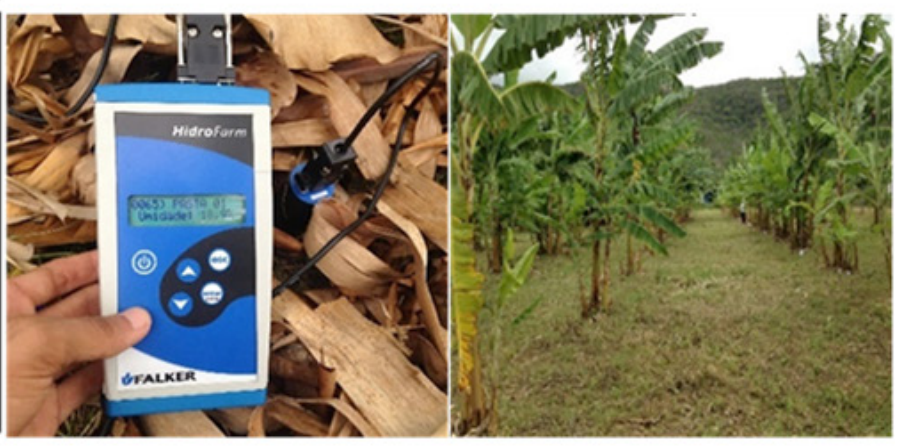

Map of Ks adapted from Santos et al. (2018)

Figure 1. Kriging maps of the variables hydraulic conductivity (A), sand (B) and silt (C), as well as experimental area (D), highlighting the sensor model used (E) and view of the banana plantation (F)

to Montenegro et al. (2013). The percentage of surface covered by leaves was equal to $100 \%$, and no soil was detected in the image processing.

Soil moisture was monitored with FALKER HidroFarm HFM 1010 sensors, which can provide instantaneous readings at $20 \mathrm{~cm}$ depth. The sensors were installed in a transect, in each sector (without and with cover), spaced by $8 \mathrm{~m}$, totaling 22 sampling points that were located at a $50 \mathrm{~cm}$ distance from the plants, in order to avoid contact with their roots. The banana root system is superficial, with higher concentration (about $90 \%$ ) up to the depth of $30 \mathrm{~cm}$ (Borges et al., 2008). Thus, the highest frequency of roots occurs in the same zone sampled by the sensor used in the study.

Measurements were performed at irregular, sub-daily time intervals: two on the first day, ten on the second and four on the third day, totaling 16 measurements. During the period, only one irrigation was performed, on the second day, immediately after the third measurement of soil moisture, respecting the irrigation schedule already used by local farmers. The others 13 measurements were performed after irrigation, during the soil drying process.

The sensor was calibrated during the soil drying process in order to simultaneously obtain readings and undisturbed samples at different moisture levels. The calibration equation, with coefficient of determination $\left(\mathrm{R}^{2}\right)$ of 0.93 , was:

Volumetric moisture $=0.0036($ sensor reading $)+0.3305$

Descriptive statistical analysis was performed by evaluating measures of central tendency, dispersion and adherence to normal distribution by the Kolmogorov-Smirnov test. To characterize the variability, the coefficients of variation $(\mathrm{CV})$ 
were analyzed as suggested by Warrick \& Nielsen (1980), who consider low variability when $\mathrm{CV}<12 \%$, medium variability for CV from 12 to $60 \%$, and high variability for $\mathrm{CV}>60 \%$.

Temporal stability analysis followed the methodology proposed by Vachaud et al. (1985), who suggest two techniques. The first, known as relative difference $(\mathrm{RD})$, performs an analysis of the deviations between the values observed individually and their mean, and can be obtained by Eq. 2 :

$$
\mathrm{RD}_{\mathrm{ij}}(\theta)=\frac{\theta_{\mathrm{ij}}-\bar{\theta}_{\mathrm{j}}}{\bar{\theta}_{\mathrm{j}}} 100
$$

where:

$\mathrm{RD}_{\mathrm{ij}}(\theta)$ - mean relative difference at position $\mathrm{i}$ and time $\mathrm{j}$;

$\theta_{\mathrm{ij}} \quad$ - soil moisture content at position i and time $\mathrm{j}$; and,

$\theta_{j} \quad$ - mean soil moisture content, at all positions, at time $\mathrm{j}$.

$\mathrm{RD}$ values close to zero indicate locations with a mean moisture content close to the mean of the area.

The second technique is the Spearman correlation test (Eq. 3 ), which is used as a statistical tool to indicate the degree of agreement of the spatial variability obtained at different points. This method makes it possible to identify the presence of temporal stability, but does not indicate which monitoring sites represent the mean in the entire area.

$$
r_{s}=1-\frac{6 \sum_{i=1}^{n}\left(R_{i j}-R_{i j}\right)^{2}}{n\left(n^{2}-1\right)}
$$

where:

$r_{s} \quad$ - Spearman correlation;

$\mathrm{R}_{\mathrm{ij}}$ - ordinate position of the variable $\theta_{\mathrm{ij}}$ observed at time $\mathrm{j}$ at point $\mathrm{i}$;

$R_{i j} \quad$ - position of the same variable observed at time $j^{\prime}$ at point i; and,

$\mathrm{n} \quad$ - number of measuring points.
After identifying the points that showed temporal stability, graphs were prepared in order to validate the behavior of the selected point during the evaluation times, comparing the individual values of the points with the overall mean, according to Fontes Júnior et al. (2012). The stable points were validated by scatter diagrams and accumulated probability diagrams. In addition, Pearson correlation coefficient ( $r$ ), bias and RMSE were also considered. In order to perform the validation by removing the most critical moment for the temporal stability (before irrigation), scatter diagrams were plotted in two conditions: with the full series of monitoring and without the readings performed before irrigation.

\section{Results AND Discussion}

The data showed normality at all times of measurement (hours) (Table 2), according to the Kolmogorov-Smirnov test of adherence to the normal distribution (ND), and the coefficients of variation (CV) indicated medium variability, according to Warrick \& Nielsen (1980). For the uncovered sector, the mean CV value was $24.51 \%$ ( \pm 1.23 ), whereas in the covered sector, the mean variation in the monitoring points was $39.86 \%$ ( $\pm 2.54 \%)$.

Greater variation in the sector with cover is justified by the interference of banana straw in the distribution of water along the evaluations, giving an initial indication that the leaves intercepted part of the water from the sprinklers. From the management point of view, these results indicate that the cover causes more accentuated variations in soil moisture temporally, as the water unevenly goes through the leaf structures over the area, which may make it difficult to adjust irrigation intervals under the evaluated condition, in the presence of cover.

Soil moisture was higher in the area that was not covered at all positions and times of monitoring. Although the cover helps reduce the evapotranspiration, contributing to the maintenance and retention of water in the soil (Montenegro et al., 2013), the leaves intercepted and accumulated part of the water in their structures, which are conducive to the deposition (Skutch,

\begin{tabular}{|c|c|c|c|c|c|c|c|c|c|c|c|c|}
\hline \multirow{3}{*}{$\begin{array}{l}\text { Times of soil } \\
\text { moisture } \\
\text { measurements }\end{array}$} & \multicolumn{12}{|c|}{ Sector } \\
\hline & \multicolumn{6}{|c|}{ Without cover $(n=100)$} & \multicolumn{6}{|c|}{ With cover $(n=100)$} \\
\hline & Mean & Median & Min. & Max. & CV (\%) & & Mean & Median & $\operatorname{Min}$. & Max. & CV (\%) & \\
\hline & \multicolumn{12}{|c|}{ Before irrigation } \\
\hline 09:30:00 & 25.7 & 25.7 & 13.1 & 27.1 & 26.4 & ND & 14.7 & 17.0 & 4.6 & 23.2 & 43.8 & ND \\
\hline $15: 10: 00$ & 24.6 & 24.6 & 12.6 & 26.3 & 26.5 & ND & 14.7 & 17.5 & 4.9 & 22.3 & 41.6 & ND \\
\hline \multirow[t]{2}{*}{$07: 20: 00$} & 23.8 & 23.8 & 11.7 & 25.8 & 28.1 & ND & 13.4 & 16.9 & 3.6 & 20.0 & 46.0 & ND \\
\hline & \multicolumn{12}{|c|}{ After irrigation } \\
\hline $12: 40: 00$ & 28.7 & 29.5 & 16.7 & 38.3 & 23.0 & ND & 15.9 & 18.6 & 4.7 & 22.2 & 37.7 & ND \\
\hline $13: 10: 00$ & 27.8 & 29.0 & 16.2 & 36.8 & 22.9 & ND & 15.7 & 18.3 & 4.5 & 22.0 & 38.1 & ND \\
\hline $13: 40: 00$ & 27.6 & 28.7 & 16.0 & 35.9 & 22.9 & ND & 15.4 & 18.0 & 4.3 & 21.5 & 38.6 & ND \\
\hline $15: 40: 00$ & 25.8 & 27.1 & 13.9 & 33.1 & 23.6 & ND & 14.8 & 17.2 & 4.5 & 21.5 & 37.5 & ND \\
\hline 16:10:00 & 26.6 & 27.6 & 14.7 & 34.7 & 23.7 & ND & 14.6 & 17.0 & 4.2 & 21.0 & 39.4 & ND \\
\hline $16: 30: 00$ & 26.9 & 28.2 & 15.1 & 34.2 & 23.1 & ND & 15.2 & 18.2 & 4.4 & 21.5 & 38.7 & ND \\
\hline $16: 50: 00$ & 26.2 & 28.1 & 14.9 & 34.3 & 23.9 & ND & 15.0 & 17.9 & 4.3 & 21.5 & 39.8 & ND \\
\hline $17: 30: 00$ & 25.9 & 27.7 & 14.1 & 34.0 & 24.7 & ND & 14.5 & 17.4 & 4.1 & 20.5 & 39.9 & ND \\
\hline $17: 50: 00$ & 27.3 & 30.1 & 14.1 & 34.8 & 25.3 & ND & 15.0 & 17.5 & 4.4 & 21.2 & 38.0 & ND \\
\hline $07: 30: 00$ & 26.2 & 27.4 & 14.6 & 34.8 & 24.3 & ND & 14.7 & 17.6 & 4.4 & 20.9 & 39.1 & ND \\
\hline 09:30:00 & 25.6 & 26.6 & 14.3 & 32.9 & 24.4 & ND & 14.5 & 17.3 & 4.8 & 20.7 & 38.4 & ND \\
\hline $11: 30: 00$ & 24.5 & 26.2 & 13.8 & 32.6 & 24.9 & ND & 14.2 & 16.6 & 4.0 & 20.3 & 39.3 & ND \\
\hline $13: 00: 00$ & 23.1 & 24.8 & 11.9 & 30.3 & 26.5 & ND & 13.5 & 15.8 & 3.4 & 18.1 & 40.1 & ND \\
\hline
\end{tabular}

Table 2. Descriptive statistics of the temporal data of soil moisture (\%) collected in the two sectors (without and with cover)

CV - Coefficient of variation; ND - Normal Distribution; $\mathrm{n}$ - Number of sampling points; Min. and Max. - Minimum and maximum values of soil moisture, respectively 
1930). Alternatives to mitigate this interference would be pre-grinding the cover or implementing a localized irrigation system, such as drip or micro-sprinkler. The costs of this management, however, are still limiting for small producers who practice family farming. During the data collection period there was no precipitation, so that the increase in soil moisture content is only due to irrigation.

Souza et al. (2011) evaluating soil moisture in carrot cultivation with and without cover composed of bean residues discarded after harvest, in an area close to that used in this study, identified higher soil moisture values in the sector with cover, but the system used was micro-sprinkler, which falls within the category of localized irrigation systems due to the higher efficiency of water application and use ( 90\%), unlike sprinklers ( 70\%) (Darko et al., 2017). The use of sprinkler irrigation causes great water loss and uneven application, especially when the system is poorly dimensioned, although this problem has not been detected in the area, based on the uniformity coefficient (CUC), which was $75.42 \%$, higher than the expected efficiency value of the method. Nonetheless, the cover with banana leaves interferes in uniformity because it naturally acts as a physical barrier that partially prevents or slows the passage of water.

Soil moisture increased after the irrigation event, carried out from the third evaluation ( $07 \mathrm{~h} 20 \mathrm{~min})$, reaching peaks that decreased slowly along the afternoon and on the next day, when there was no more water depth application until the end of the monitoring. During the entire period, the lowest mean values of soil moisture recorded were $23.8 \%$ in the sector without cover and $13.4 \%$ in the sector with cover, which represents difference of $77.61 \%$, demonstrating once again, under these conditions, the lower water use in the covered area, although both sectors have been equally irrigated.

There was variation between the sensors (Figure 2), in the two sectors, possibly related to soil particle size and saturated hydraulic conductivity (Ks), which varied along the plot. As presented in Figure 1, sand content increases in one direction of the area, associated with higher mean values of Ks, at some points. Kunz et al. (2014) emphasize that areas with higher Ks are expected to have higher infiltration rate and, consequently, faster reduction of moisture content in the surface layer.

Melo \& Montenegro (2015), evaluating the spatial and temporal behavior of moisture on watershed scale, identified the sensitive relationship of moisture content with type of soil, with higher mean values of moisture in clayey soils, demonstrating the dynamics of this variable as a function of particle size.

As for the temporal correlation between the measurements performed, most of the Spearman correlation coefficients obtained, at all times and in both sectors, were close to $1(\mathrm{p}<0.05)$, indicating the existence of temporal stability. Thus, all the monitoring intervals showed a significant correlation for the studied sectors. The short evaluation time and absence of rainfall naturally favor higher values of correlation, especially in the uncovered sector, where water is more evenly distributed. These data can help in irrigation management, since they indicate, especially under semiarid conditions, the maintenance of soil moisture, i.e., the persistence of the soil in storing water for a certain period (Carvalho et al., 2017). In

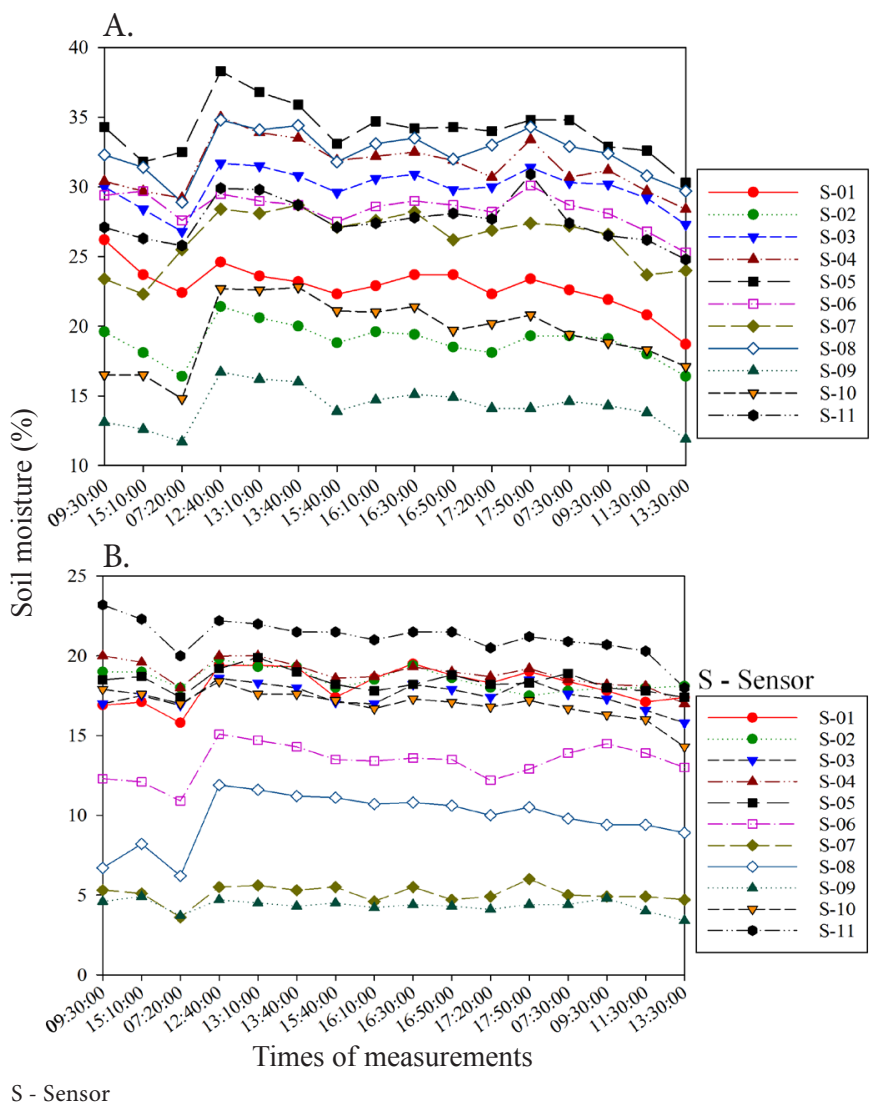

Figure 2. Comparison between soil moisture in the sectors without cover (A) and with cover (B) at different points (sensors) and times of measurement

order to better visualize this pattern, the Spearman correlation matrix for the monitored times was represented in the form of box plot, for both sectors (Figure 3).

In relation to temporal stability, Figures $4 \mathrm{~A}$ and $\mathrm{B}$ present the relative differences (RD) and the respective standard deviations, as well as the validation for the areas without and with cover. These data make it possible to visualize which monitoring point(s) is(are) closest to the mean soil moisture in the entire study area, so they can be selected as a sampling reference (Souza et al., 2011; Carvalho et al., 2017).

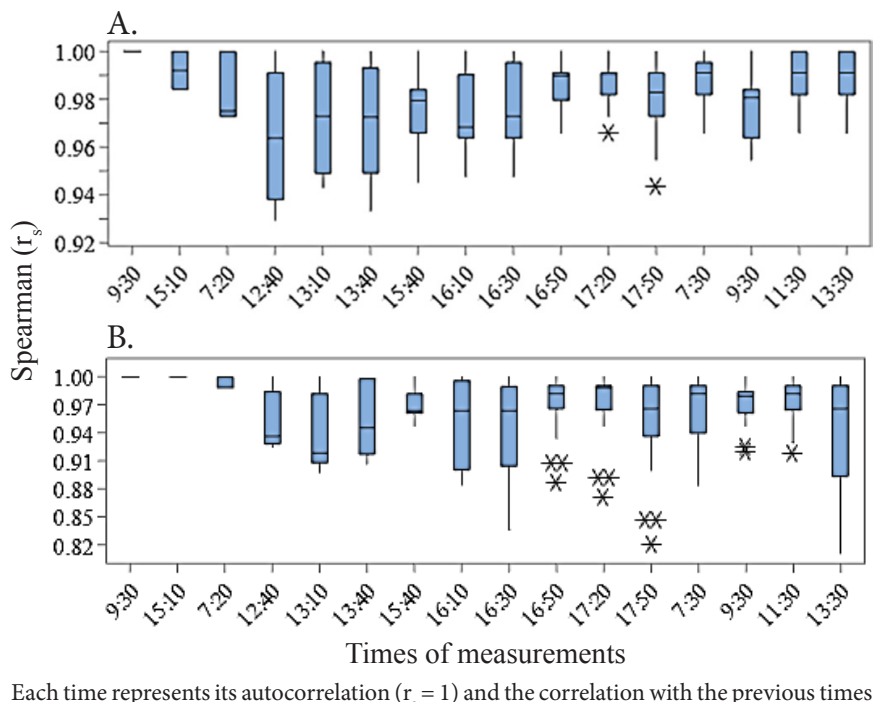

Figure 3. Box plot representing the temporal correlations of soil moisture in the sectors without cover (A) and with cover (B) 
A.
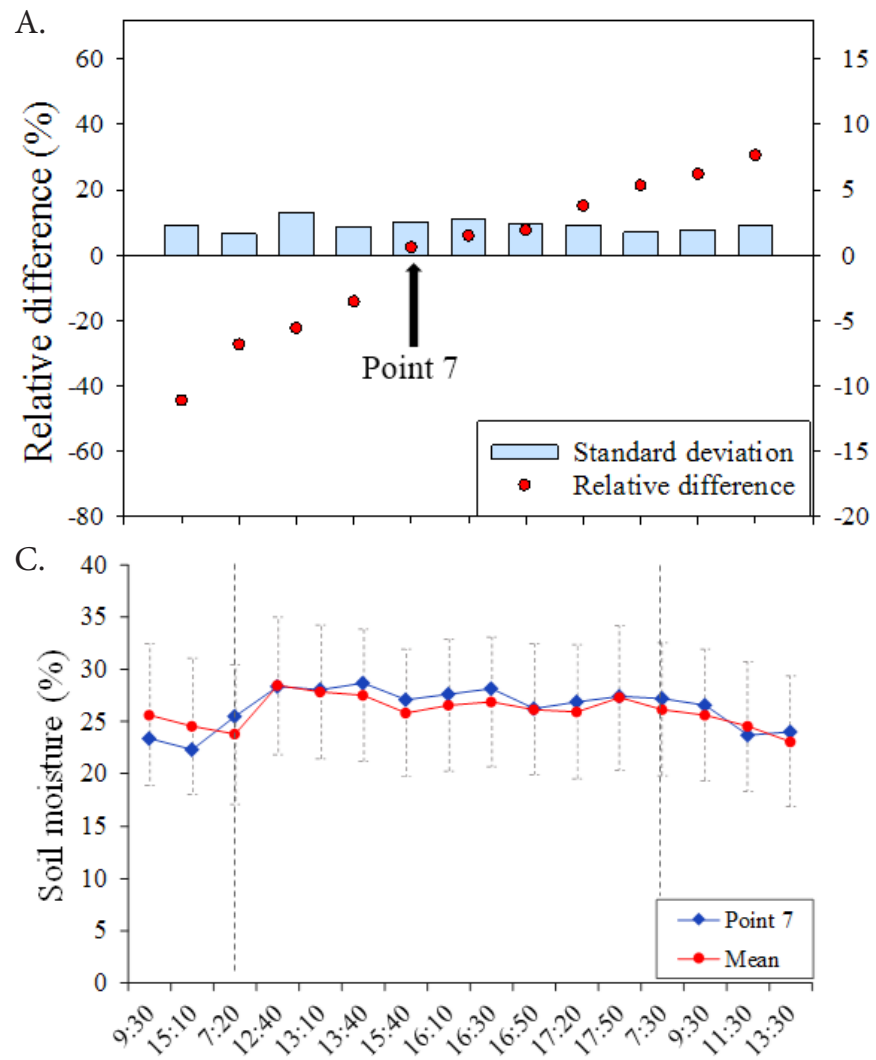

B.

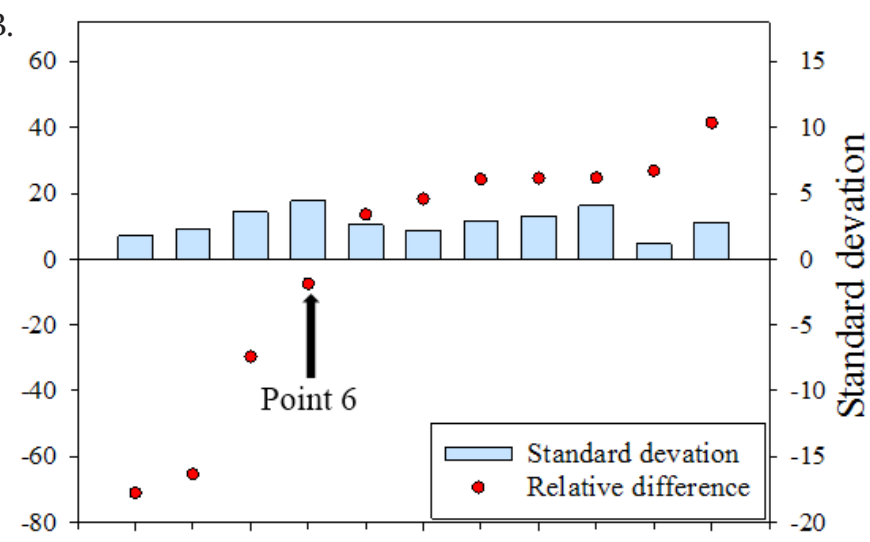

D. 30

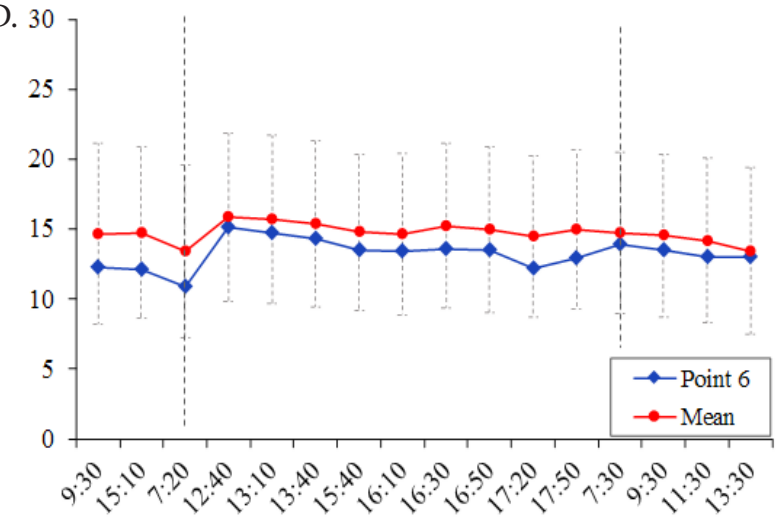

Times of measurements

Highlighted values indicate the closest points to the mean at any time; Vertical bars in Figures 4C and D express standard deviation and dashed lines separate the different moments considered in the temporal stability analysis

Figure 4. Mean relative difference (RD) and standard deviation of soil moisture in the sectors without (A) and with cover (B); $\mathrm{C}, \mathrm{D}$ - comparison between the mean values of soil moisture and the stable point

In the area without cover, the measurement point with $\mathrm{RD}$ closest to zero was 7 , with a value of $2.40( \pm 2.54 \%)$. For the sector with cover, the most representative point was 6 , with RD of $-7.47( \pm 4.43 \%)$. The two points are close and in texture-transition area, where there is a reduction in sand fraction and increase in clay and silt fractions, which favor water storage and retention, indicating that this zone is the most promising for continuous monitoring of moisture, representative of the entire area. This indicates that, in future monitoring, these points can be adopted as a reference to give a representative mean value of soil moisture in the area. In the production system based on family farming, simple and with low technological level, this is a very promising option due its low cost, for not requiring the installation of sensors at various points in the area.

Salvador et al. (2012), working in a $1500 \mathrm{~m}^{2}$ area cultivated alternately with beans and black oat in the municipality of Piracicaba, SP, Brazil, with regular grid of 60 points spaced by $5 \mathrm{~m}$, found similar values of standard deviations. Despite working under other conditions, Wang et al. (2016), in a semiarid region of China, also obtained $\mathrm{RD}$ values varying within a wide range when all points were plotted side by side on the graph, indicating that some points tend to be more representative than others to express the mean soil moisture in the area. For those with temporal stability, the RD was close to zero and the standard deviation was low. According to Vachaud et al. (1985), the point to be selected for future observations should be the one which has $\mathrm{RD}$ very close to zero, associated with a low standard deviation.
In order to further detail the dynamics of temporal stability, soil moisture data were separated into three main moments: before irrigation, from the reading performed shortly after irrigation until the monitoring prior to the antepenultimate reading (Figure 3 ). The most critical moment was that prior to irrigation, with root mean squared errors (RMSE) of 2.11 and $2.51 \%$ in the sectors without and with cover, respectively. In the sector with cover, the RMSE values of the second and third moments were 1.25 and $1.83 \%$. The moments of soil drying were the ones which most affected the representativeness of the stable point in this sector. In the sector with uncovered soil, the error changed from 0.90 to $0.82 \%$ in the second and third moments, evidencing the influence of soil cover on the temporal stability.

Based on the comparative charts between the points considered more stable and the mean of the entire area, it can be noted that the stable point in the sector without cover tends to underestimate (bias $=-0.33 \%$ ) soil moisture, as opposed to the stable point in the covered sector (bias $=1.63 \%$ ) (Figures $5 \mathrm{~A}$ and D). In the sector without cover, the values tend to fluctuate, becoming higher than the mean at some of the times, which led to a lower correlation coefficient, although the errors were lower compared to the sector with cover.

For the uncovered sector, the values of the stable point and the mean of the area tended to approach after filtration, during the soil drying process, which can be confirmed by the increase in Pearson correlation coefficient ( $r$ ) and reduction in root mean squared error (RMSE). For the sector with cover, the tendency was inverse for the correlation coefficient, but there 
A.

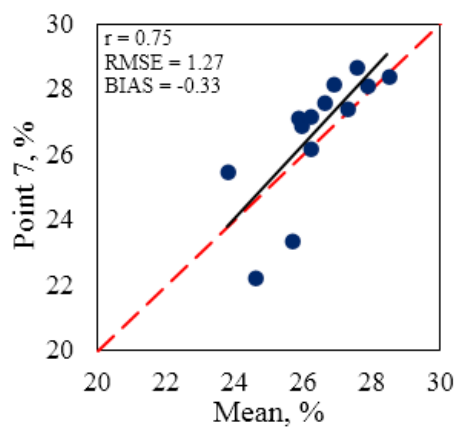

D.

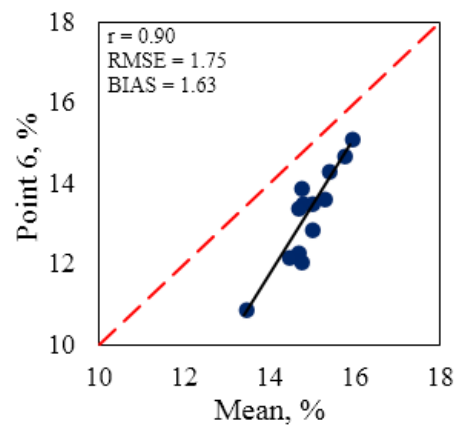

B.

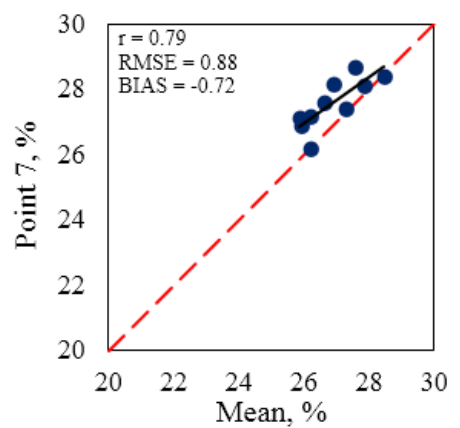

E.

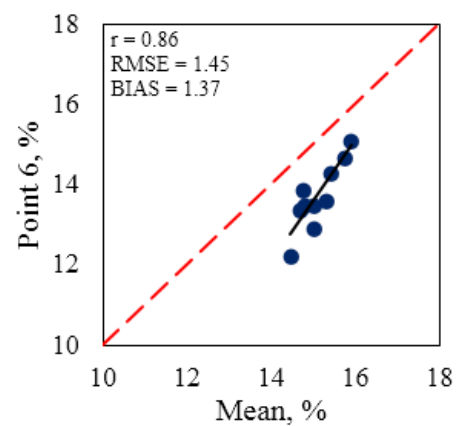

C.

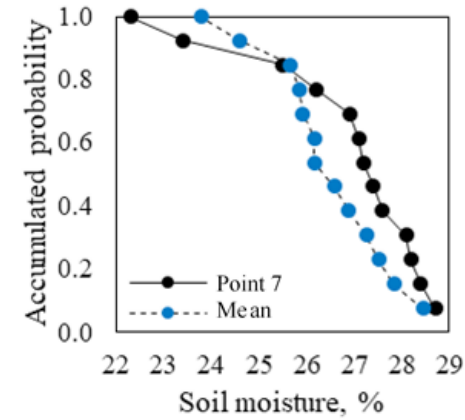

F.

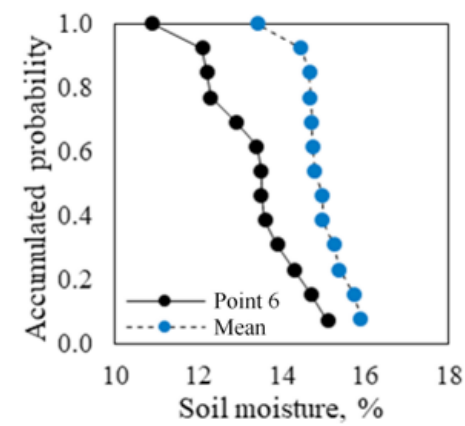

RMSE - Root mean squared error

Figure 5. Correlation and accumulated frequency between the stable point and the mean of the other points monitored in the experimental area, under the conditions without cover and with cover, respectively. A, D - correlations with the full series of monitoring; B, E - correlation with monitoring performed after irrigation; C, F - accumulated probability of soil moisture data under both conditions

was also a reduction in the errors. It should be considered that, in both cases, the moment before irrigation was the one which led to greater discrepancies between soil moisture values at the stable point and the mean of the area.

Through the graphs of accumulated frequency, it is possible to see again the tendency of the sector without cover to have shown greater similarity between the measurements recorded at the stable point compared to the mean, which demonstrates that the temporal stability is influenced by both irrigation and the presence of cover.

\section{Conclusions}

1. The morphology of the banana leaves and the irrigation system used contributed to lower soil moisture in the covered sector at all monitoring times.

2. Variations in the physical-hydraulic properties of the soil promoted variations in soil moisture with the position of the sensors in the ground.

3. The temporal stability technique allowed the identification of points that represent the mean behavior of soil moisture throughout the area.

4. The use of banana leaf residues caused less soil wetting using sprinkler irrigation, indicating the need to pre-grind the material or use localized irrigation systems, practices that are not very accessible to family farmers.

\section{ACKNOWLEDGMENTS}

To the Terra Foundation for granting the area to conduct this study; to the technician Tiago, for the support in the field; to FINEP for funding the REHYDRO 1830 project; to CNPq for the Research Productivity (PQ) grant and for funding the projects Universal - MCTI/CNPq No 14/2014, MCTI/ CNPq/ANA No 23/2015 and INCT-MC (Climate Changes); to FACEPE for granting the master's scholarship.

\section{Literature Cited}

Borges, A. L.; Souza, L. S.; Peixoto, C. A. B.; Santos Junior, J. L. C. dos. Distribuição do sistema radicular da bananeira 'Prata-Anã' em duas frequências de irrigação com ureia. Revista Brasileira de Fruticultura, v.30, p.259-262, 2008. https://doi.org/10.1590/ S0100-29452008000100048

Brocca, L. Ciabatta, L.; Massari, C.; Camici, S.; Tarpanelli, A. Soil moisture for hydrological applications: Open questions and new opportunities. Water, v.9, p.1-20, 2017. https://doi.org/10.3390/ w9020140

Carvalho, A. A. de; Silva, T. G. F. da; Queiroz, M. G. de; Araújo Júnior, G. do N.; Jardim, A. M. de R. F.; Souza, C. A. A. de. Estabilidade temporal e variabilidade espacial da umidade de um argissolo cultivado com palma forrageira. Revista Brasileira de Agricultura Irrigada, v.11, p.1998-2009, 2017. https://doi.org/10.7127/rbai. v11n700667

Cintra, F. L. D.; Resende, R. S.; Procópio, S. O. Cobertura morta com folhas secas de coqueiro em sistemas de produção de coco irrigado. In: Seminário sobre Manejo Sustentável para a Cultura do Coqueiro, Aracaju. Anais... Brasília: EMBRAPA, 2017.

Darko, R. O.; Shouqi, Y.; Junping, L.; Haofang, Y.; Xingye, Z. Overview of advances in improving uniformity and water use efficiency of sprinkler irrigation. International Journal of Agricultural and Biological Engineering, v.10, p.1-15, 2017. 
Fontes Júnior, R. V. de P.; Montenegro, A. A. de A.; Montenegro, S. G. L. M.; Santos, T. E. M. dos. Estabilidade temporal da potenciometria e da salinidade em vale aluvial no semiárido de Pernambuco. Revista Brasileira de Engenharia Agrícola e Ambiental, v.16, p.1188-1197, 2012. https://doi.org/10.1590/S1415-43662012001100007

Freire, J. A. Política agrícola e sustentabilidade da agricultura familiar no Nordeste brasileiro: anos 90. Raízes, v.20, p.76-89, 1999.

Guanziroli, C. E.; Sabbato, A. di; Vidal, M. F. Evolução da agricultura familiar nordestina: Uma análise comparativa entre os dois sensos agropecuários. Revista Econômica do Nordeste, v.45, p.93-105, 2014.

Kunz, J.; Ávila, V. S.; Petry, M. Distribuição temporal e espacial da umidade do solo em sistemas de irrigação por gotejamento subsuperficial. Revista Monografias Ambientais, v.13, p.39633976, 2014. https://doi.org/10.5902/2236130815123

Lopes, I.; Montenegro, A. A. A.; Lima, J. L. M. P. Performance of conservation techniques for semiarid environments: Field observations with Caatinga, mulch, and cactus forage palma. Water, v.11, p.1-15, 2019. https://doi.org/10.3390/w11040792

Melo, R. O.; Montenegro, A. A. de A. Dinâmica temporal da umidade do solo em uma bacia hidrográfica no semiárido Pernambucano. Revista Brasileira de Recursos Hídricos, v.20, p.430-441, 2015. https://doi.org/10.21168/rbrh.v20n2.p430-441

Montenegro, A. A. de A.; Abrantes, J. R. C. B.; Lima, J. L. M. P. de; Santos, T. E. M. Impact of mulching on soil water dynamics under intermittent simulated rainfall. Catena, v.109, p.139-149, 2013. https://doi.org/10.1016/j.catena.2013.03.018

Montenegro, A. A. de A.; Montenegro, S. M. G. L. Variabilidade espacial de classes de textura, salinidade e condutividade hidráulica de solos em planície aluvial. Revista Brasileira de Engenharia Agrícola e Ambiental, v.10, p.30-37, 2006. https:// doi.org/10.1590/S1415-43662006000100005

Rodrigues, R. A. S.; Montenegro, A. A. A.; Santos, D. P. dos; Magalhães, A. G.; Fontes Júnior, R. P. Variabilidade espacial da umidade e das frações granulométricas do solo em um plantio de bananeiras irrigado no semiárido pernambucano. Conexões - Ciência e Tecnologia, v.11, p.134-143, 2017. https://doi.org/10.21439/ conexoes.v11i3.884
Salvador, M. M. S.; Libardi, P. L.; Brito, A. S.; Moreira, N. B. Estabilidade temporal e variabilidade espacial da distribuição da armazenagem de água no solo numa sucessão feijão/aveia-preta. Revista Brasileira de Ciências do Solo, v.36, p.1801-1810, 2012. https://doi.org/10.1590/S0100-06832012000500007

Santos, D. P.; Montenegro, A. A. de A.; Rodrigues, R. A. S.; Araújo, D. C. dos S.; Santos, C. S.; Cruz Neto, J. F. da C. Variabilidade especial de atributos físicos do solo em vale aluvial na região de Pernambuco. Revista Brasileira de Agricultura Irrigada, v.12, p.2271-2282, 2018. https://doi.org/10.7127/rbai.v12n100647

Silva Junior, V. de P.; Montenegro, A. A. de A.; Melo, R. O. Temporal stability of soil moisture in an experimental watershed in the Pernambuco semi-arid region. Revista Brasileira de Engenharia Agrícola e Ambiental, v.20, p.880-885, 2016. https://doi. org/10.1590/1807-1929/agriambi.v20n10p880-885

Skutch, A. F. On the development and morphology of the leaf of the banana (Musa sapientum L.). American Journal of Botany, v.17, p.252-271, 1930. https://doi.org/10.1002/j.1537-2197.1930. tb09548.x

Souza, E. R. de; Montenegro, A. A. de A.; Montenegro, S. M. G.; Matos, J. A. Temporal stability of soil moisture in irrigated carrot crops in Northeast Brazil. Agricultural Water Management, v.99, p.26-32, 2011. https://doi.org/10.1016/j.agwat.2011.08.002

Vachaud, G.; Silans, A. P. de; Balabanis, P.; Vauclin, M. Temporal stability of spatially measured soil water probability density function. Soil Science Society of America Journal, v.49, p.822-828, 1985. https://doi.org/10.2136/sssaj1985.03615995004900040006x Wang, S.; Fu, B.; Liu, J. Soil moisture temporal stability analysis for typical hilly and gully re-vegetated catchment in the Loess Plateau, China. Environmental Earth Sciences, v.75, p.1-9, 2016. https:// doi.org/10.1007/s12665-016-5572-y

Warrick, A. W.; Nielsen, D. R. Spatial variability of soil physical properties in the field. In: Hillel, D. (ed.). Applications of soil physics. New York: Academic Press, 1980. 350p. https://doi. org/10.1016/B978-0-12-348580-9.50018-3 